The Geography of Chronic Pain in the United States and Canada.

Anna Zajacova, University of Western Ontario0F ${ }^{1}$

Jinhyung Lee, University of Western Ontario

Hanna Grol-Prokopczyk, University at Buffalo, State University of New York

September 15, 2021

\begin{abstract}
Our understanding of population pain epidemiology is largely based on national-level analyses. This focus, however, neglects potential cross-national, and especially sub-national, geographic variations in pain, even though geographic comparisons could shed new light on factors that drive or protect against pain. This article presents the first comparative analysis of pain in the U.S. and Canada, comparing the countries in aggregate and analyzing variation across states and provinces. Analyses are based on cross-sectional data collected in 2020 from 2,124 U.S. and 2,110 Canadian adults 18 years and older. Our pain measure is a product of pain frequency and pain-related interference with daily activities. We use regression and decomposition methods to link socioeconomic characteristics and pain, and inverse-distance weighting spatial interpolation to map pain scores. We find significantly and substantially higher pain in the U.S. than in Canada. The difference is accounted for by Americans' lower economic wellbeing. Additionally, we find variation in pain within countries; the variation is statistically significant across U.S. states. Further, we identify nine hotspot states in the Deep South, Appalachia, and the West where respondents have significantly higher pain than those in the rest of the U.S. or Canada. This excess pain is partly attributable to economic distress, but a large part remains unexplained; we speculate that it may reflect the sociopolitical context of the hotspot states. Overall, our findings identify areas with high need for pain prevention and management; they also other scholars to consider geographic factors as important contributors to population pain.
\end{abstract}

\footnotetext{
${ }^{1}$ Corresponding author. Mailing address: 5330 Social Science Centre, University of Western Ontario, London ON, N6A 5C2, Canada. Email: anna.zajacova@uwo.ca. Phone: 519-282-2049. Institutional URL: https://uwo.ca/.'
} 


\section{The Geography of Chronic Pain in the United States and Canada.}

Our understanding of the epidemiology of chronic pain remains incomplete. One critical gap is the near absence of research on the geographic distribution of pain, especially at sub-national but also cross-national levels. Using unique cross-sectional data collected in 2020 from U.S. and Canadian respondents, we answer two key questions: (1) How is chronic pain geographically distributed in the U.S. and Canada, both with respect to the two countries in aggregate and within each country across states and provinces? And (2) how do population characteristics explain observed geographic differences in pain scores? Further, our analyses identify pain "hotspots," examine predictors of excess pain in the hotspots, and, more broadly, invite future research to consider geographic factors as contributors to population pain.

The U.S. and Canada share many characteristics: Both are wealthy economies with highly educated, predominantly English-speaking, diverse populations and, according to most if not all classifications, share the "liberal" welfare-state regime designation [2; 39]. At the same time, they differ in important ways. Canada has lower poverty rates, less socioeconomic inequality, a stronger social safety net, and, unlike the U.S., a universal health care system [41; 48]. Perhaps due to these differences, studies often-although not always-find longer lifespans and better health in Canada [14; 17]. However, no study to date has compared pain between these neighboring countries. Our U.S.-Canada comparison offers insights about social factors shaping pain at the national level.

Neither the U.S. nor Canada, however, is a monolithic entity. Both countries comprise subnational units--states and provinces - that are increasingly heterogeneous with respect to health determinants [16;31]. These include socioeconomic factors at the individual level, and specific policies as well as overall policy orientations at the macro level $[13 ; 16]$.

Correspondingly, states and provinces vary substantially in health and mortality [27; 32; 52]; the variation is increasing over time [57]. For instance, age-standardized prevalence of disability, an important (often pain-related) dimension of health, is about $7 \%$ in Minnesota and North Dakota but over $13 \%$ in Kentucky or Mississippi [34]. Life expectancy also ranges widely across states and provinces, with a 6-year gap between the most and least healthy U.S. states [1], and a 3year gap across Canadian provinces [49] -- or an 11-year gap, with the inclusion of the Northern territory of Nunavut [50]. Yet, research has nearly uniformly neglected subnational variability in pain and/or its predictors [13], as reflected by the absence of studies on pain prevalence across states and provinces.

Our study provides the first detailed examination of pain's geographic distribution both across and within the U.S. and Canada, using a relatively fine-grained pain measure that combines pain frequency and pain-related interference with daily activities. Our findings identify hotspot areas with a particularly high need for pain prevention and treatment; clarify the role of demographic and socioeconomic population characteristics in explaining cross- and withincountry differences; and pave the road for future studies of contextual factors that may help explain excess pain in hotspot regions.

\section{METHODS}

\section{Data}

We use the Recovery and Resilience COVID-19 data [51]. This cross-sectional dataset was developed by an interdisciplinary team of social science investigators at the University of 
Western Ontario and administered by Leger Opinion in the U.S. and Canada in August of 2020 [51]. The aim of the survey was to assess a wide range of sociopolitical, economic, and other conditions in the summer of 2020 in the two countries. The online survey was completed by 2,124 U.S. and 2,110 Canadian respondents aged 18 and older who were a part of an ongoing Leger Opinion Panel. The percentage of the panel respondents invited to participate in the survey who responded was $17 \%$ in Canada and $25 \%$ in the U.S. A small number of respondents were ineligible due to their age (below 18) or their responses were eliminated due to low quality; the final response rate was $13 \%$ in Canada and $19 \%$ in the U.S. (We briefly discuss the response rate in the discussion section.) The samples were designed to be nationally representative of age, gender, and Census region in the U.S. and provinces in Canada, and sampling weights were provided by Leger to correct for over- and under-sampling; the weighted sample is representative of the population with respect to these three characteristics. The survey was approved by the Ethics Board of the University of Western Ontario (Project ID 116046).

\section{Variables}

Pain was assessed with two questions. First, respondents were asked: "in the past 30 days... How often have you experienced pain?" The response options were never or almost never, rarely, sometimes, often, almost always, and always (coded as 0-5). Respondents who chose an option other than 'never or almost never' were then asked: "how much did the pain interfere with your general activity like work or household chores?" This item was assessed on an 11point scale from 'did not interfere' to 'completely interfered.' The pain score was created as the arithmetic product of these two variables (frequency and interference). This merged score yielded a scale from 0 to 55 . The score of 0 is for respondents who reported they experienced pain "never or almost never," while 55 is for those reporting that they 'always' had pain that 'completely interfered' with their everyday activities. This variable had a right-skewed distribution, which we found to be best modeled using negative binomial regressions. We also dichotomized the full scale for sensitivity analyses using 2 thresholds: a pain score of at least 10 and a pain score of at least 20 . The threshold of 10 corresponds to a less stringent pain definition that included even relatively infrequent and low-interference pain, such that $42.5 \%$ of the combined U.S./Canada target population reported pain above that threshold. The threshold of 20 is a more stringent pain definition reflecting either more frequent or higher-impact pain, reported by $21.4 \%$ of the target population.

State and province of residence was reported by the respondents; U.S. respondents chose from a list of states and Canadian respondents from a list of provinces.

Age was collected using the following categories: 18-24, 25-34, 35-44, 45-54, 55-64, and 65+. We collapsed the middle categories in some analyses for parsimony, generating categories of 18-24, 25-44, 45-64, and 65+. These two specifications yielded substantively identical results. Gender was collected as male (reference), female, or other. Race was recoded to white (reference), Black, Hispanic, Asian, and other. Immigrant status was a dichotomy of native-born (reference) versus immigrant. Marital status was coded as married (reference, includes common-law), previously married, and never married. Respondents also reported whether they had children or not (reference). Education was coded as high school or less, some postsecondary education, associate degree or equivalent, and bachelor's degree or more (reference). Main activity status included the categories employed (reference), retired, unemployed, disabled, and other. Finally, respondents were asked about their family income and financial hardships due to COVID-19, which can be viewed as indicators of longer-term and short-term economic well-being or stress. Family income was categorized as $\$ 0-29,000$ 
(reference); $\$ 30-59,000, \$ 60-89,000,90-149,000$, and $\$ 150,000$ or more. The same categories were used in the U.S. and in Canada, without identifying dollars as U.S. or Canadian. We did not convert the currency because we felt that these five broad categories captured the relative income standing in each country sufficiently well. Financial hardship was measured with the question "Are you feeling financial hardship due to COVID-19?" and coded as no hardship (reference), little or slight hardship, some hardship, or serious hardship.

\section{Approach}

Our approach had three major analytic steps. We first calculated univariate and bivariate (U.S. versus Canada) descriptive statistics. Specifically, we estimated weighted pain scores in the aggregate and for each sociodemographic group in each country; we also tested whether the mean pain scores differed between the two countries, using group-specific bivariate negative binomial regression models on a country indicator (Table 1). We also estimated the distribution of all covariates in each country, and tested for differences in the distributions between the two countries using design-adjusted F-tests (Supplemental Table S1).

In our second major analytic step, we analyzed differences between U.S. and Canada in aggregate, using two complementary approaches: nonlinear decomposition (Table 2) and a series of regression models (Supplemental Table S2). The Oaxaca-Blinder nonlinear decomposition is a widely-used econometric method that quantifies how much of the difference in pain prevalence between the U.S. and Canada is due to different population characteristics (composition) or different coefficient effects (also referred to unexplained part) [3; 40]. More formally, the observed difference in pain prevalence $\bar{y}_{U S}-\bar{y}_{C a n}$, where $\bar{y}_{U S}$ is the mean pain level in the U.S. and $\bar{y}_{C a n}$ is the mean pain level in Canada, is defined as $\bar{y}_{U S}-\bar{y}_{C a n}=$ $F\left(X_{U S} \hat{\beta}_{U S}\right)-F\left(X_{C a n} \hat{\beta}_{C a n}\right)$, where the $X_{U S}$ and $X_{C a n}$ are vectors of observed covariates in the U.S. and Canada, respectively. Their associated vectors of coefficients $\hat{\beta}$ s are estimated using a negative binomial model appropriate to the skewed positive distribution of the pain scores, and $F()$ is the cumulative distribution function of the negative binomial distribution. The term $F\left(X_{U S} \hat{\beta}_{C a n}\right)$ can be added and then subtracted to obtain: $\bar{y}_{C a n}-\bar{y}_{U S}=\left[F\left(X_{C a n} \hat{\beta}_{C a n}\right)-\right.$ $\left.F\left(X_{U S} \hat{\beta}_{C a n}\right)\right]+\left[F\left(X_{U S} \hat{\beta}_{C a n}\right)-F\left(X_{U S} \hat{\beta}_{U S}\right)\right]$. The first bracket captures the gap between the two countries due to differences in population characteristics while the second bracket captures the part due to differences in coefficients. We used the mvdcmp extension in Stata for decomposition [43], combined with the new utility for grouping individual covariates for detailed decomposition, mvdcmpgroup (Powers 2020, personal communication). The effects of categorical variables in this approach are normalized as deviations from the grand mean, which enables calculation of effects for all levels, and yields results that are identical regardless of which category is the reference [22]. In the supplement, we also show the more widely used, though more constrained, approach to examining the country-level differences: a series of weighted negative binomial regression models with an indicator for the U.S., net of different sets of covariates. The drawback in the regression models is that the effect of all covariates is constrained to be equal in both countries, effectively equivalent to forcing the coefficient effect (unexplained part) in the decomposition to be equal to zero.

Our third major analytic step was to analyze the pain scores at the level of subnational units, that is, states in the U.S. and provinces in Canada. First, we mapped the geographic distribution of weighted mean pain scores in the U.S. and Canada (Figure 1). The inverse distance weighting (IDW) spatial interpolation technique [26] was used to estimate pain scores for 
unsampled locations using values from surrounding locations, thereby generating a continuous surface of weighted mean pain scores across the U.S. and Canada. Table 3 provides a different perspective: it lists weighted mean pain scores in each state/province with at least 15 respondents, ranked from highest to lowest score. Table 3 also lists estimated proportions of residents with pain scores $\geq 10$ and $\geq 20$, respectively, as robustness checks. These descriptive steps identified a set of hotspot states with the highest pain levels. We then tested whether the pain scores vary significantly across all subnational units via a likelihood ratio F-tests of joint significance (Supplemental Table S3). Finally, we used nonlinear decomposition (Table 4) and negative binomial regression models (Supplemental Table S4), akin to the methods in Tables 2 and $\mathrm{S} 2$, to examine the sources of the excess pain in the hotspot areas.

All analyses were weighted. Data cleaning and most analyses were conducted in Stata 17; the mapping was done in ArcMap 10.8.1.

\section{RESULTS}

Table 1 summarizes weighted mean pain scores in the U.S. and Canada, both within the full sample and in population subgroups. In the total sample, the mean pain score was $12.5(95 \% \mathrm{Cl}$ $12.0,13.1)$ in the U.S. and $10.7(95 \% \mathrm{Cl} 10.2,11.3)$ in Canada, a statistically significant difference $(p<.001)$. We also dichotomized the pain score at three cutpoints. For each of these specifications, again, pain was significantly higher in the U.S.: Americans had 5.8 percentage points (pp) greater change of pain $\geq 10,4.9$ pp greater chance of pain $\geq 20$, and 4.2 pp greater chance of pain $\geq 30$.

In every subgroup, pain was either statistically significantly higher in the U.S., or the betweencountry difference was not significant. The groups with the highest average pain scores in both countries were those who reported serious financial hardship due to COVID-19 (with average pain scores of 22.2 in the U.S. [95\% Cl 19.3, 25.2] and 19.4 in Canada [95\% Cl 15.9, 22.9]), and respondents who described their main activity status as "disabled" $(25.5$ in the U.S. [95\% 22.6, 28.4] and 32.3 in Canada [95\% Cl 28.0, 36.5]). Further, we note an interesting general pattern whereby the U.S. pain 'excess' vis-à-vis Canada tends to be most pronounced among more socially advantaged groups. That is, the pain 'excess' in the U.S. versus in Canada is statistically significant for white, non-immigrant, college-educated, employed, high-income, and no/little financial hardship groups. The differences are smaller and not significant among those who are non-white, immigrant, low-educated or recipients of a subbaccalaureate degree like associate degree or vocational/technical certificate, lower income, and experiencing some/serious financial hardship due to COVID-19.

Supplemental Table S1 summarizes the distribution all covariates in the U.S. and Canadian samples and shows $p$-values from tests for differences in the distribution of each covariate between the countries. The two samples differ with respect to several demographic characteristics, in particular race/ethnicity and immigrant status, but also gender. The U.S. adult population comprises more Black and Hispanic respondents than the Canadian population, where Asian Canadian and 'other' groups predominate among non-white groups. Additionally, the U.S. sample includes $7.5 \%$ immigrant adults, compared to $19.3 \%$ in Canada. Race/ethnicity and immigrant status matter greatly in analyses of pain because immigrants report less pain than native-born adults, at least in the U.S. [18; 58; 59]. There are important racial/ethnic differences in pain prevalence as well [36; 42; 60], with adults of Asian heritage tending to report particularly low pain prevalence [25; 35]. With respect to gender, pain differences are well 
known; women report greater pain prevalence, severity, and interference, compared with men [4; 44; 54]. Thus, inter-country differences in race/ethnicity, immigrant status, and gender may shape overall country differences in pain. The U.S. and Canadian samples also differ in socioeconomic status indicators. The U.S. has significantly lower educational attainment and family income, and U.S. respondents reported significantly greater financial hardship due to COVID-19 (all $p<.001$ ). Given that socioeconomic status is one of the most important social factors in pain [21; 29; 45], we next examine how these differences impact pain in both countries.

Our second step was to analyze the sources of the pain score difference between the U.S. and Canada. Table 2 shows the proportion of the observed pain score difference which can be attributed to differences in composition (population characteristics) versus differences in coefficient effects (unexplained part). The total decomposition shows that $82.2 \%$ of the gap in the mean pain scores between the two countries is due to differences in composition (characteristics) while $17.8 \%$ is unexplained, that is, due to differences in coefficient effects. The detailed decomposition shows how the covariates, grouped for parsimony, add up to these total percentages. Nearly half of the compositional difference is from economic factors, i.e., main activity, family income, and financial hardship $(48.1 \%, p<.001)$. As we summarized in Table $S 1$, U.S. respondents have lower family income and greater financial hardship than their Canadian counterparts. The second major source is the different race and immigrant status composition $(26.3 \%, \mathrm{p}<.01)$. This is also unsurprising given the high proportion of Canadians who are immigrants or Asian Canadians, characteristics associated with particularly low chronic pain prevalence as noted in the prior paragraph. None of the coefficient differences, whether total or specific to any group of covariates, is a statistically significant contributor to explaining the U.S. excess in pain.

Supplemental Table S2 corroborates this picture with a set of regression models of pain scores as a function of the U.S. indicator and covariates. This set of models effectively constrains the effect of all covariates to be equal in the U.S. and Canada since interaction terms are not included; however, this constraint is reasonable since the decomposition analysis found no statistically significant differences in the coefficient effects. The results show that the incidence rate ratio (IRR) of pain is 1.17 in the U.S. relative to Canada, whether or not we control for age and gender distribution (Models 1 and 2, both $p<.001$ ). Race and immigrant status attenuate the U.S. pain disadvantage somewhat (IRR=1.14, $\mathrm{p}<.001$ in Model 3) while marital status and children are not significant predictors and correspondingly change the U.S.-Canada difference little (IRR=1.13, $\mathrm{p}<.01$ in Model 4). Just as the decomposition analysis showed, economic indicators, included in Models 5-8, are significant predictors of pain and jointly also explain the U.S. excess pain, which is no longer significant in Models 6 or 8 (IRR=1.07 and 1.05, respectively; $p>.05$ in both cases). Education is a suppressor: controlling for this covariate actually makes the U.S. disadvantage significant, with or without inclusion of economic indicators (IRR=1.08, p<.05 in Model 10). In sum, the decomposition and regression analyses show that most although not all of the higher pain score in the U.S. compared with Canada is due to (a) the greater economic stress among U.S. adults, and (b) racial/immigrant compositional differences between the two countries.

The analyses thus far treated both countries as monolithic units, when in reality they comprise potentially heterogeneous subnational units. Therefore, we next examine how pain varies within each country across states and provinces. Figure 1 shows a map of weighted mean pain scores 
in the U.S. and Canada. The map highlights the relatively low average pain scores across most of Canada (blue hue) except Newfoundland and Labrador, as well as across much of the U.S. Midwest and Northeast. The figure also shows that pain is substantially higher in much of the U.S. Deep South and parts of the Appalachia, as well as select areas of the West and Northwest (particularly Oregon and Nevada), as the red hue indicates.

We also quantified the mean pain levels by state or province. Table 3 shows the mean pain scores, as well as the proportion of respondents whose pain scores exceed 10 points and 20 points, respectively, in each state or province with at least 15 respondents, ordered from highest to lowest mean scores. The left panel in the table lists U.S. states; the right panel lists Canadian provinces. The average pain scores in U.S. states range from about 10 points in lowa, Missouri, Massachusetts, and --surprisingly, given its overall poor health [53]-- Louisiana, to 17 or above in Arkansas, Tennessee, and Mississippi. The proportions with pain (using either the 10- or 20point thresholds to dichotomize the pain scores) yield generally comparable ranking of states. The range of pain scores across Canadian provinces, in the right-hand side panel, is substantially smaller. The pain scores range from about 8-10 in Prince Edward Island, Quebec, and Ontario, to less than 13 in Newfoundland and Labrador, New Brunswick, and Saskatchewan. All the Canadian provinces have pain scores on par with the lower half of U.S. states. In other words, about half of U.S. states have pain scores higher than any province in Canada.

Is the subnational heterogeneity statistically significant? Supplemental Table S3 answers this question by testing the joint effects of U.S. states, Canadian provinces, and all subnational units jointly, in negative binomial regression models of pain net of different covariate sets. The variation is significant in the null model $(p<.05)$ and marginally when we control for age and sex $(p<.10)$ when we analyzed all subnational units, that is, states and provinces together. When we control for additional characteristics, however, the joint effect of subnational units is not significant. The variation is not statistically significant for any U.S. and Canada-specific models, perhaps because of the relatively modest sample sizes for most subnational units (Supplemental Table S4 lists the sample sizes for each state and province).

However, although the variability of all subnational units is only marginally significant net of age and sex, the high level of pain in the states with the highest pain scores warrants further examination. We designated states with average pain score $\geq 15$ as "hotspot" states. The hotspot states included Arkansas, Tennessee, Mississippi, Alabama, Kentucky, Kansas, Georgia, Oregon, and Nevada, states clustered in the Deep South, parts of Appalachia and the Northwest. We next tested whether the hotspot states differ significantly from the rest of the subnational units, using nonlinear decomposition and also regression models.

The results from negative binomial regression models of pain net of an indicator for the hotspot states (Arkansas, Tennessee, Mississippi, Alabama, Kentucky, Kansas, Georgia, Oregon, and Nevada) versus all other subnational units, net of all covariate sets, are shown in Supplemental Table S5. The Table shows that the IRR of pain in hotspot states is $1.45(p<.001)$ higher relative to all other units in unadjusted Model 1. About a third of this excess pain appears to be due to economic factors, especially family income. Controlling for these covariates (Models 6-9) attenuates the U.S. excess by about one third (IRR=1.29, $p<.001$ in Model 9). However, even after controlling for all covariates, the hotspot states still have significantly higher pain than other subnational units $(\mathrm{IRR}=1.30, \mathrm{p}<.001)$, highlighting that much of the difference in pain levels remains unexplained. We also note that the difference between the hotspot states versus all 
other units is considerably greater than the differences between the U.S. and Canada, which highlights that the within-country variation can be, and in our case is, greater than the crosscountry difference.

A complementary portrait of the sources of the hotspots' excess pain is in Table 4, which shows results from a nonlinear decomposition in which we decompose the difference in pain in the hotspot states versus all other states and provinces. The results show that $41.8 \%$ of the pain excess in the hotspot states is due to differences in the distribution of the observed population characteristics between these hotspots and other states/provinces. The majority of this explained (compositional) part is economic factors $(33.7 \%, p<.01)$, which is similar to the result from the regression models in Supplemental Table S5. Over 58\% of the hotspot excess, however, is 'unexplained,' that is, due to different effects of observed characteristics on pain or a residual difference in the intercepts due to factors not included in the study. Thus, both regression and decomposition perspectives suggest that the pain excess in the hotspot areas is due partly to economic disadvantage of the hotspot-area residents, but in large part to factors beyond those we included in the analysis.

\section{DISCUSSION}

The Federal Pain Research Strategy has declared that the "greatest near-term value" research priority to better understand pain disparities is to "better define the epidemiology of pain in disparate populations," and the "most impactful top priority" is to investigate mechanisms, including social mechanisms, that contribute to group differences in chronic pain [20, p. 18]. Our analysis contributes directly to these priorities. Using a new international survey that allowed us to combine pain frequency and interferences with daily activities, we compared population pain levels in the United States and Canada at the aggregate national level and tested social correlates of observed differences. Further, we examined geographic variation in pain across states and provinces, identified hotspots with particularly high pain levels, and checked whether these hotspots are a function of sociodemographic characteristics within those areas.

We found that pain is significantly higher on average in the U.S. than in Canada. This was the case regardless of whether we used a continuous pain score for the comparison, or a dichotomized scale. The latter showed a 4-6 percentage point higher pain burden in the U.S. across different scale cutpoints. This difference is clinically meaningful and translates to roughly 10 million extra U.S. adults experiencing pain compared to what it would be at the Canadian levels. While ours is the first comparative study of pain in these two countries, our findings corroborate relevant comparative analyses, which found worse health and higher mortality in the U.S. than in Canada $[5 ; 14 ; 17]$.

The higher pain burden in the U.S. versus Canada appears to be a function of the worse economic conditions of U.S. adults, including greater likelihood of low income and financial hardship. The importance of these factors is unsurprising, as the strong impact of economic distress on physical pain has been well documented $[6 ; 23 ; 29 ; 55 ; 56]$. Our counterfactual decomposition suggests that if family income and financial hardship were equal in the U.S. and Canada, there might be no difference in the pain burden between the two countries.

Additionally, the decomposition showed that the effects of socioeconomic factors on pain were comparable in the U.S. and Canada. This is an important finding because it confirms the link between socioeconomic factors and pain burden at a national level, which in turn contributes to the foundational evidence base regarding the importance of social roots of pain. 
However, the pain patterns were more complex at the subnational level. We found variation across states/provinces, although it was statistically significant only for all subnational units together, not when U.S. states and Canadian provinces were examined separately. In Canada, the pain scores ranged from about 8-10 in Quebec, Ontario, and Prince Edward Island, to around 12-13 in the Atlantic provinces of Newfoundland and Labrador and New Brunswick; the Prairies and the Canadian West were roughly in the middle. This general geographic pattern fits the findings of the only prior study estimating province-specific pain prevalence, which used a large nationally-representative Canadian health survey [47].

The pain scores ranged more widely in the U.S., from about 10 in lowa, Missouri, and Massachusetts, to over 23 in Arkansas. Overall, about half of U.S. states had pain burden within the range observed across Canadian provinces, while the other half had more pain than found in any Canadian province. Indeed, some states had such high pain burden relative to all other sub-national units (pain score $\geq 15$ ) that we designated these states as pain "hotspots." These comprise the primarily Southern and Appalachian states of Arkansas, Tennessee, Mississippi, Alabama, Kentucky, Georgia, as well as Kansas, and Western states of Oregon and Nevada. Jointly, these hotspot areas have a significantly and substantially greater pain burden than other states and provinces, about $45 \%$ higher incidence rate. There are no prior analyses of pain burden across U.S. states to compare our findings to; indeed, the majority of studies on U.S. population pain burden include no geographic indicators [7; 11; 15; 61]. However, several studies described U.S. pain by Census region and reported higher chronic pain in the South [37] or West [24; 59] and less in the Northeast [37; 58]. Our findings are generally consistent with these patterns, as well as with geographic patterns in other dimensions of health, which tends to note particularly high rates of mortality [32; 57], disability [34], and risk factors such as smoking [8] and obesity [9] in the Deep South and Appalachia states.

The absence of geographic variation in population pain is particularly surprising when contrasted with a much better understanding of variation in pain treatment, especially opioid use and misuse, across U.S. states and Canadian provinces. The hotspot areas we identified with respect to pain overlap with areas of high opioid use: Appalachia and the South [10], and states in the Pacific Northwest [28; 46]. Whether this overlap is coincidental, causal, or confounded by common causes, it requires further investigation, and we urge the collection and public-use dissemination of data that would enable scholars to examine the geography of chronic pain.

About $33-42 \%$ of the excess pain in the hotspot areas is due to differences in sociodemographic factors and economic conditions (with the lower bound of this range based on regression analyses, and the upper bound based on decomposition). The majority of the pain excess, however, is due to factors unobserved in our study. Such factors may include sociopolitical features of the hotspot states, such as health care system generosity, minimum wage floors, taxation, housing policies, environmental protection, and even structural sexism and racism, all of which are connected to population health [19; 30; 32]. These sociopolitical features reflect states' overall policy orientations: For instance, Minnesota supports their residents' health and wellbeing more than a state like Mississippi, and such policy differences are then powerfully reflected in the overall health and mortality of these states' residents [33]. It is reasonable to expect that such state differences would also be reflected in pain burden. Other unobserved drivers of the excess pain in the hotspot areas could also be additional factors measured at the individual level, such as obesity or social support. However, it is important to remember that federal, state, or local contexts and policies are crucial in shaping individual circumstances, as 
well as their effect on health. Future research could consider the role of national or subnational policies (e.g., redistributive taxes such as the Earned Income Tax Credit, food stamp eligibility, Medicaid or other health insurance eligibility policies, and other social safety net features) in shaping pain, via mechanisms like income and financial hardship.

Our conclusions are limited by sample size and representativeness. While our total sample exceeds 4,000 (with over 2,000 respondents in each country), the subnational analyses, especially with respect to the 50 U.S. states, would ideally be based on a larger sample. Thus, our conclusions about any single state, especially outliers like Arkansas and Louisiana (both of which had only 21 respondents), must be viewed as provisional. Louisiana's low pain burden was particularly unexpected due to its low position in health and longevity rankings [34; 38; 53]. We note that pain levels in Louisiana were not actually the lowest in our dataset, rather, states including South and North Dakota, Hawaii, and Utah had lower pain scores, as could be expected on the basis of their overall healthy profiles [34; 38]. However, they included fewer than 15 respondents, which we set a priori as a threshold for presenting state-specific findings.

The Recovery and Resilience COVID-19 survey's low response rate, moreover, raises the possibility of biased selection into the sample. The distribution of sample characteristics indeed suggests that both the U.S. and Canadian samples undersampled disadvantaged respondents, such as those of low socioeconomic status (SES). The sampling weights adjust for age, sex, and region/province distribution, but not for SES or other characteristics. This suggests that our aggregate estimates of pain scores likely underestimate the true burden since the omitted disadvantaged adults would likely report higher pain [12; 59]. However, there is no reason to believe that the selection processes into the U.S. versus Canadian samples, or into samples in individual states and provinces, would differ systematically and bias the reported comparisons.

\section{Conclusion}

Overall, population pain is higher in the U.S. than in Canada, largely due to the worse economic conditions among U.S. adults. While our associational cross-sectional study does not allow us to make policy recommendations, these findings suggest that easing Americans' economic stress may, in addition to other benefits, lessen the pain burden experienced by the population. Additionally, pain variation across states and provinces was even larger than between the two countries. In particular, a portion of U.S. states in the Deep South, parts of Appalachia and the West had pain levels high enough to be designated as "hotspots." We posit that state policy orientation and context may help explain the hotspots' excess pain. Future analyses should draw on cross-national and sub-national variation in pain as fresh lens to uncovering the macroto individual-level social roots of population pain.

\section{Acknowledgements}

This study was supported in part by the National Institute on Aging (R01AG055481, R01AG06535101A1) and the Canadian Social Science and Humanities Research Council Insight Grant. The authors thank Cecilia Diaz Campo, Dr. Jason Winders, Dr. Autumn Knowlton, and Lindsay Finlay for their invaluable assistance with manuscript and analysis development, and Dr. Laura Stephenson for leading the development of the survey instrument and data collection.

All authors declare no conflict of interests. 


\section{REFERENCES}

[1] Arias E, Bastian B, Xu J, Tejada-Vera B. U.S. State Life Tables, 2018. National Vital Statistics Reports 2021;70(1):1-18.

[2] Bambra C. Going beyond The three worlds of welfare capitalism: regime theory and public health research. Journal of Epidemiology and Community Health 2007;61(12):10981102.

[3] Blinder AS. Wage Discrimination: Reduced Form and Structural Estimates. The Journal of Human Resources 1973;8(4):436-455.

[4] Boerner KE, Chambers CT, Gahagan J, Keogh E, Fillingim R, Mogil J. Conceptual complexity of gender and its relevance to pain. PAIN 2018;159(11):2137-2141.

[5] Boyle Torrey B, Haub C. A Comparison of US and Canadian Mortality in 1998. Population and Development Review 2004;30(3):519-530.

[6] Case A, Deaton A. The Misery and Mystery of Pain. Deaths of Despair and the Future of Capitalism. Princeton NJ: Princeton University Press, 2020. pp. 83-93.

[7] Case A, Deaton A, Stone AA. Decoding the mystery of American pain reveals a warning for the future. Proceedings of the National Academy of Sciences 2020;117(40):2478524789.

[8] CDC. Current Cigarette Smoking Among Adults in the United States, Vol. 2020. Bethesda, MD: Centers for Disease Control and Prevention, 2019.

[9] CDC. Adult Obesity Prevalence Maps, Vol. 2020. Bethesda, MD: Centers for Disease Control and Prevention, 2020.

[10] Centers for Disease Control and Prevention. U.S. Opioid Dispensing Rate Maps, Vol. 2021: Centers for Disease Control and Prevention, National Center for Injury Prevention and Control, n.d.

[11] Cutler DM, Meara E, Stewart S. Socioeconomic Status and the Experience of Pain: An Example from Knees. NBER Working Paper, Vol. 27974. Cambridge, MA: National Bureau of Economic Research, 2020.

[12] Dahlhamer J, Lucas J, Zelaya C, Nahin R, Mackey S, DeBar L, Kerns R, Von Korff M, Porter L, Helmick C. Prevalence of chronic pain and high-impact chronic pain among adults-United States, 2016. Morbidity and Mortality Weekly Report 2018;67(36):1-6.

[13] Daigneault P-M, Birch L, Béland D, Bélanger S-D. Taking subnational and regional welfare states seriously: Insights from the Quebec case. Journal of European Social Policy 2021;31(2):239-249.

[14] Feeny D, Kaplan MS, Huguet N, McFarland BH. Comparing population health in the United States and Canada. Population Health Metrics 2010;8(1):8.

[15] Grol-Prokopczyk H. Sociodemographic disparities in chronic pain, based on 12-year longitudinal data. Pain 2017;158(2):313-322.

[16] Grumbach J. From Backwaters to Major Policymakers: Policy Polarization in the States, 1970-2014. Perspectives on Politics 2018;16(2):416-435.

[17] Guyatt GH, Devereaux P, Lexchin J, Stone SB, Yalnizyan A, Himmelstein D, Woolhandler S, Zhou Q, Goldsmith LJ, Cook DJ, Haines T, Lacchetti C, Lavis JN, Sullivan T, Mills E, Kraus S, Bhatnagar N. A systematic review of studies comparing health outcomes in Canada and the United States. Open fMed 2007;1(1):e27-e36.

[18] Hamilton ER, Hale JM, Savinar R. Immigrant Legal Status and Health: Legal Status Disparities in Chronic Conditions and Musculoskeletal Pain Among Mexican-Born Farm Workers in the United States. Demography 2019;56(1):1-24.

[19] Homan P, Brown TH, King B. Structural Intersectionality as a New Direction for Health Disparities Research. Journal of Health and Social Behavior 2021:00221465211032947.

[20] Interagency Pain Research Coordinating Committee. Federal Pain Research Strategy. Bethesda, MD: National Institutes of Health, 2018. 
[21] Janevic MR, McLaughlin SJ, Heapy AA, Thacker C, Piette JD. Racial and Socioeconomic Disparities in Disabling Chronic Pain: Findings From the Health and Retirement Study. The Journal of Pain 2017;18(12):1459-1467.

[22] Jann B. The Blinder-Oaxaca decomposition for linear regression models. Stata Journal 2008;8(4):453-479.

[23] Jay MA, Bendayan R, Cooper R, Muthuri SG. Lifetime socioeconomic circumstances and chronic pain in later adulthood: findings from a British birth cohort study. BMJ Open 2019;9(3):1-10.

[24] Johannes CB, Le TK, Zhou X, Johnston JA, Dworkin RH. The Prevalence of Chronic Pain in United States Adults: Results of an Internet-Based Survey. The Journal of Pain 2010;11(11):1230-1239.

[25] Loder S, Sheikh HU, Loder E. The Prevalence, Burden, and Treatment of Severe, Frequent, and Migraine Headaches in US Minority Populations: Statistics From National Survey Studies. Headache: The Journal of Head and Face Pain 2015;55(2):214-228.

[26] Longley PA, Goodchild MF, Maguire DJ, Rhind DW. Geographic information systems and science: John Wiley \& Sons, 2005.

[27] Martin D, Miller AP, Quesnel-Vallée A, Caron NR, Vissandjée B, Marchildon GP. Canada's universal health-care system: achieving its potential. The Lancet 2018;391(10131):17181735.

[28] McDonald DC, Carlson K, Izrael D. Geographic Variation in Opioid Prescribing in the U.S. The Journal of Pain 2012;13(10):988-996.

[29] Men F, Fischer B, Urquia ML, Tarasuk V. Food insecurity, chronic pain, and use of prescription opioids. SSM - Population Health 2021;14:100768.

[30] Montez JK. Policy Polarization and Death in the United States. Temple Law Review 2020;92:889.

[31] Montez JK. US State Polarization, Policymaking Power, and Population Health. The Milbank Quarterly 2020;98(4):1033-1052.

[32] Montez JK, Beckfield J, Cooney JK, Grumbach JM, Hayward MD, Koytak HZ, Woolf SH, Zajacova A. US State Policies, Politics, and Life Expectancy. The Milbank Quarterly 2020;98(3):668-699.

[33] Montez JK, Farina MP. Do Liberal US State Policies Maximize Life Expectancy? Public Policy Aging Rep 2021;31(1):7-13.

[34] Montez JK, Zajacova A, Hayward MD. Disparities in Disability by Educational Attainment Across US States. American Journal of Public Health 2017;107:1101-1108.

[35] Nahin RL. Estimates of Pain Prevalence and Severity in Adults: United States, 2012. The Journal of Pain 2015;16(8):769-780.

[36] Nahin RL. Pain Prevalence, Chronicity and Impact Within Subpopulations Based on Both Hispanic Ancestry and Race: United States, 2010-2017. The Journal of Pain 2021 ;Available online 23 February 2021.

[37] Nahin RL, Sayer B, Stussman BJ, Feinberg TM. Eighteen-Year Trends in the Prevalence of, and Health Care Use for, Noncancer Pain in the United States: Data from the Medical Expenditure Panel Survey. The journal of pain 2019.

[38] National Center for Health Statistics CfDCaP. Underlying Cause of Death 1999-2019 on CDC WONDER Online Database, released in 2020., 2020.

[39] News US. Overall Best Countries Ranking, 2021.

[40] Oaxaca R. Male-Female Wage Differentials in Urban Labor Markets. International Economic Review 1973;14(3):693-709.

[41] OECD. Poverty rate (indicator), 2021.

[42] Pitcher MH, Von Korff M, Bushnell MC, Porter L. Prevalence and Profile of High-Impact Chronic Pain in the United States. The Journal of Pain 2019;20(2):146-160. 
[43] Powers DA, Yoshioka H, Yun M-S. Mvdcmp: Multivariate Decomposition for Nonlinear Response Models. The Stata journal 2011;11(4):556-576.

[44] Racine M, Tousignant-Laflamme Y, Kloda LA, Dion D, Dupuis G, Choinière M. A systematic literature review of 10years of research on sex/gender and experimental pain perception - Part 1: Are there really differences between women and men? PAIN 2012;153(3):602618.

[45] Riskowski JL. Associations of Socioeconomic Position and Pain Prevalence in the United States: Findings from the National Health and Nutrition Examination Survey. Pain Medicine 2014;15(9):1508-1521.

[46] Schieber LZ, Guy GP, Jr, Seth P, Young R, Mattson CL, Mikosz CA, Schieber RA. Trends and Patterns of Geographic Variation in Opioid Prescribing Practices by State, United States, 2006-2017. JAMA Network Open 2019;2(3):e190665-e190665.

[47] Schopflocher D, Taenzer P, Jovey R. The Prevalence of Chronic Pain in Canada. Pain Research and Management 2011;16(6):445-450.

[48] Siddiqi A, Kawachi I, Keating DP, Hertzman C. A Comparative Study of Population Health in the United States and Canada during the Neoliberal Era, 1980-2008. International Journal of Health Services 2013;43(2):193-216.

[49] Statistics Canada. Table 13-10-0114-01 Life expectancy and other elements of the life table, Canada, all provinces except Prince Edward Island. Ottawa, ON, 2020.

[50] Statistics Canada. Table 13-10-0140-01 Life expectancy and other elements of the life table, Prince Edward Island and the territories. Ottawa, ON, 2020.

[51] Stephenson LB, Esses V, Goode M, Zajacova A, al. e. Recovery \& Resilience COVID-19 Survey. In: University of Western Ontario editor. London, Canada, 2020.

[52] The US Burden of Disease Collaborators. The State of US Health, 1990-2016: Burden of Diseases, Injuries, and Risk Factors Among US States. JAMA 2018;319(14):1444-1472.

[53] United Health Foundation. America's Health Rankings Annual Report, 2018 Edition. America's Health Rankings. Minnetonka, MN, 2018.

[54] Unruh AM. Gender variations in clinical pain experience. Pain 1996;65(2):123-167.

[55] Warth J, Puth M-T, Tillmann J, Porz J, Zier U, Weckbecker K, Münster E. Overindebtedness and its association with pain and pain medication use. Preventive Medicine Reports 2019;16:1-6.

[56] Wilkinson LR, Schafer MH, Wilkinson R. How painful is a recession? An assessment of two future-oriented buffering mechanisms. Social Science \& Medicine 2020;255:112455.

[57] Woolf SH, Schoomaker H. Life Expectancy and Mortality Rates in the United States, 19592017. JAMA 2019;322(20):1996-2016.

[58] Zajacova A, Grol-Prokopczyk H, Zimmer Z. Pain Trends Among American Adults, 20022018: Patterns, Disparities, and Correlates Demography 2021;58(2):711-738.

[59] Zajacova A, Rogers RG, Grodsky E, Grol-Prokopczyk H. The Relationship between Education and Pain among Adults Aged 30-49 in the United States. Journal of Pain 2020;21(11-12):1270-1280.

[60] Zelaya CE, Dahlhamer JM, Lucas JW, Connor EM. Chronic Pain and High-impact Chronic Pain Among U.S. Adults, 2019. NCHS Data Brief, Vol. 390. Hyattsville, MD: National Center for Health Statistics, 2020.

[61] Zimmer Z, Zajacova A. Persistent, Consistent and Extensive: The Trend of Increasing Pain Prevalence in Older Americans. J Gerontol 2020;75(2):436-447. 
medRxiv preprint doi: https://doi.org/10.1101/2021.09.15.21263635; this version posted September 20, 2021. The copyright holder for this preprint (which was not certified by peer review) is the author/funder, who has granted medRxiv a license to display the preprint in perpetuity.

It is made available under a CC-BY 4.0 International license .

\begin{tabular}{|c|c|c|c|c|c|}
\hline \multirow[b]{2}{*}{ Pain score in full sample } & \multicolumn{2}{|r|}{ U.S. } & \multicolumn{2}{|r|}{ Canada } & \multirow{2}{*}{$\begin{array}{l}\text { p-value from Wald } \\
\text { test of difference } \\
<.001\end{array}$} \\
\hline & 12.5 & $(12.0,13.1)$ & 10.7 & $(10.2,11.3)$ & \\
\hline \multicolumn{6}{|l|}{ Pain score, by age } \\
\hline $18-24$ & 8.0 & $(6.6,9.3)$ & 8.0 & $(6.9,9.1)$ & .969 \\
\hline $25-44$ & 13.6 & $(12.4,14.8)$ & 10.1 & $(9.3,10.9)$ & $<.001$ \\
\hline $45-64$ & 13.8 & $(12.6,14.9)$ & 11.5 & $(10.5,12.4)$ & .002 \\
\hline $65+$ & 11.2 & $(9.8,12.6)$ & 11.8 & $(10.5,13.0)$ & .553 \\
\hline \multicolumn{6}{|l|}{ Pain score, by gender } \\
\hline Men & 11.7 & $(10.8,12.6)$ & 9.7 & $(8.9,10.4)$ & .001 \\
\hline Women & 13.4 & $(12.5,14.3)$ & 11.7 & $(10.9,12.4)$ & .004 \\
\hline \multicolumn{6}{|c|}{ Pain score, by race/ethnicity } \\
\hline Non-Hispanic white & 13.1 & $(12.3,13.9)$ & 11.2 & $(10.5,11.8)$ & $<.001$ \\
\hline Non-white & 10.7 & $(9.6,11.9)$ & 9.4 & $(8.4,10.3)$ & .071 \\
\hline \multicolumn{6}{|c|}{ Pain score, by immigrant status } \\
\hline Not immigrant & 12.9 & $(12.2,13.5)$ & 11.0 & $(10.4,11.6)$ & $<.001$ \\
\hline Immigrant & 8.5 & $(6.5,10.6)$ & 9.4 & $(8.4,10.4)$ & .474 \\
\hline \multicolumn{6}{|l|}{ Pain score, by education } \\
\hline High school or less & 13.1 & $(11.6,14.6)$ & 12.9 & $(11.5,14.2)$ & .819 \\
\hline Some postsecondary & 14.6 & $(13.1,16.0)$ & 11.7 & $(10.4,13.0)$ & .004 \\
\hline AA or VTC & 13.5 & $(11.6,15.4)$ & 13.5 & $(12.2,14.9)$ & .984 \\
\hline BA or higher & 10.9 & $(10.0,11.8)$ & 8.1 & $(7.5,8.7)$ & $<.001$ \\
\hline \multicolumn{6}{|c|}{ Pain score, by main activity } \\
\hline Employed & 11.2 & $(10.4,12.1)$ & 9.4 & $(8.7,10.0)$ & $<.001$ \\
\hline Retired & 12.1 & $(10.5,13.7)$ & 11.9 & $(10.7,13.1)$ & .874 \\
\hline Unemployed & 13.0 & $(10.7,15.3)$ & 11.5 & $(9.3,13.6)$ & .335 \\
\hline Disabled & 25.5 & $(22.6,28.4)$ & 32.3 & $(28.0,36.5)$ & .008 \\
\hline Other & 11.5 & $(9.9,13.0)$ & 9.1 & $(7.9,10.3)$ & .020 \\
\hline \multicolumn{6}{|c|}{ Pain score, by family income } \\
\hline $0-29 k$ & 15.7 & $(14.4,16.9)$ & 14.7 & $(13.2,16.2)$ & .352 \\
\hline $30-59 k$ & 11.7 & $(10.5,12.9)$ & 12.0 & $(10.8,13.1)$ & .751 \\
\hline $60-89 k$ & 10.8 & $(9.3,12.4)$ & 9.8 & $(8.8,10.8)$ & .249 \\
\hline $90 \mathrm{k}$ or more & 10.2 & $(9.1,11.4)$ & 8.2 & $(7.5,8.9)$ & .002 \\
\hline \multicolumn{6}{|c|}{ Pain score, by financial hardship ${ }^{1}$} \\
\hline No hardship & 9.6 & $(8.7,10.6)$ & 8.0 & $(7.4,8.7)$ & .005 \\
\hline Slight/little hardship & 12.3 & $(11.3,13.2)$ & 11.0 & $(10.2,11.8)$ & .041 \\
\hline Some hardship & 14.7 & $(12.8,16.6)$ & 16.4 & $(14.4,18.3)$ & .232 \\
\hline Serious hardship & 22.2 & $(19.3,25.2)$ & 19.4 & $(15.9,22.9)$ & .229 \\
\hline \multicolumn{6}{|l|}{ Dichotomized pain score } \\
\hline Pain $\geq 10$ & $45.4 \%$ & $(42.9 \%, 47.9 \%)$ & $39.6 \%$ & $(37.5 \%, 41.8 \%)$ & $<.001$ \\
\hline Pain $\geq 20$ & $23.9 \%$ & $(21.8 \%, 25.9 \%)$ & $19.0 \%$ & $(17.3 \%, 20.7 \%)$ & $<.001$ \\
\hline Pain $\geq 30$ & $13.0 \%$ & $(11.4 \%, 14.6 \%)$ & $8.8 \%$ & $(7.6 \%, 10.1 \%)$ & $<.001$ \\
\hline
\end{tabular}

Weighted means and $95 \%$ confidence intervals. Pain is a continuous variable with $0-55$ range. $N=4,162$. The $p$-values are from Wald tests for a U.S. dummy (versus Canada) in weighted negative binomial bivariate regression of pain estimated separately for each group.

1 Financial hardship due to COVID-19 
medRxiv preprint doi: https://doi.org/10.1101/2021.09.15.21263635; this version posted September 20, 2021. The copyright holder for this preprint (which was not certified by peer review) is the author/funder, who has granted medRxiv a license to display the preprint in perpetuity.

It is made available under a CC-BY 4.0 International license .

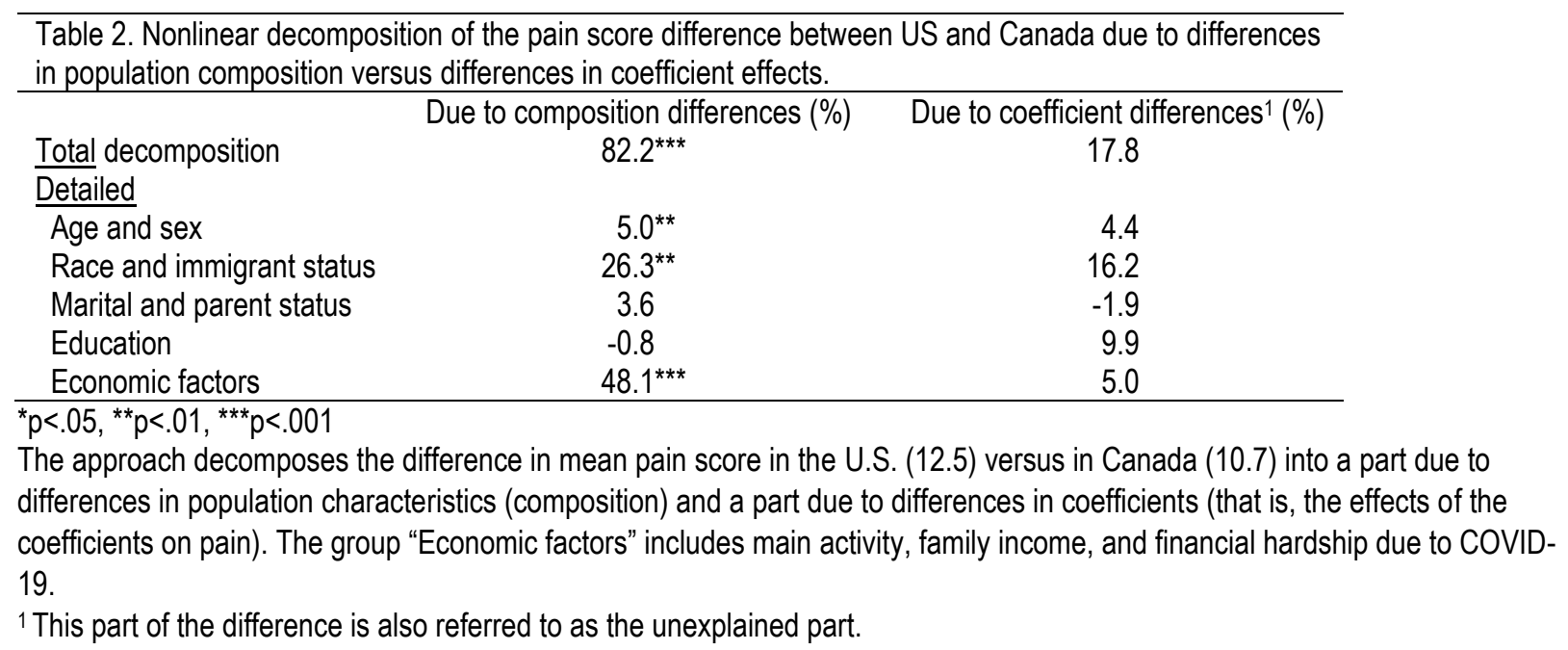


medRxiv preprint doi: https://doi.org/10.1101/2021.09.15.21263635; this version posted September 20, 2021. The copyright holder for this preprint (which was not certified by peer review) is the author/funder, who has granted medRxiv a license to display the preprint in perpetuity.

It is made available under a CC-BY 4.0 International license .

\begin{tabular}{|c|c|c|c|c|c|c|c|}
\hline & $\begin{array}{l}\text { Mean pain } \\
\text { score }\end{array}$ & $\begin{array}{l}\% \text { with } \\
\text { pain } \geq 10\end{array}$ & $\begin{array}{l}\% \text { with } \\
\text { pain } \geq 20\end{array}$ & & $\begin{array}{l}\text { Mean pain } \\
\text { score }\end{array}$ & $\begin{array}{l}\% \text { with } \\
\text { pain } \geq 10\end{array}$ & $\begin{array}{l}\% \text { with } \\
\text { pain } \geq 20\end{array}$ \\
\hline Arkansas & 23.4 & 74.4 & 54.8 & & & & \\
\hline Tennessee & 17.5 & 62.2 & 40.3 & & & & \\
\hline Mississippi & 17.0 & 56.0 & 41.5 & & & & \\
\hline Alabama & 16.9 & 60.6 & 36.8 & & & & \\
\hline Kentucky & 16.8 & 59.9 & 33.1 & & & & \\
\hline Kansas & 16.3 & 42.4 & 34.5 & & & & \\
\hline Georgia & 15.8 & 55.1 & 32.8 & & & & \\
\hline Oregon & 15.6 & 56.1 & 39.1 & & & & \\
\hline Nevada & 15.1 & 48.5 & 26.1 & & & & \\
\hline North Carolina & 14.7 & 50.1 & 27.7 & & & & \\
\hline Texas & 14.5 & 53.4 & 30.3 & & & & \\
\hline Pennsylvania & 14.2 & 41.0 & 28.0 & & & & \\
\hline Indiana & 14.1 & 58.0 & 27.2 & & & & \\
\hline Virginia & 13.7 & 53.4 & 19.5 & & & & \\
\hline Florida & 13.6 & 50.5 & 24.0 & & & & \\
\hline Connecticut & 13.3 & 46.8 & 29.2 & & & & \\
\hline Maryland & 13.2 & 52.3 & 18.6 & & & & \\
\hline Washington & 13.1 & 40.3 & 23.6 & & & & \\
\hline Arizona & 13.1 & 43.6 & 23.9 & & & & \\
\hline Minnesota & 13.0 & 42.5 & 30.6 & & & & \\
\hline \multirow{2}{*}{ Oklahoma } & 12.9 & 38.5 & 23.9 & & & & \\
\hline & & & & Newfoundland \& Labrador & 12.7 & 36.5 & 23.7 \\
\hline New York & 12.5 & 45.4 & 19.9 & & & & \\
\hline \multirow[t]{3}{*}{ Ohio } & 12.1 & 44.2 & 20.7 & & & & \\
\hline & & & & New Brunswick & 11.7 & 44.0 & 25.8 \\
\hline & & & & Saskatchewan & 11.7 & 48.8 & 19.9 \\
\hline New Jersey & 11.5 & 42.5 & 19.5 & & & & \\
\hline Wisconsin & 11.5 & 39.6 & 21.4 & & & & \\
\hline \multirow[t]{2}{*}{ Michigan } & 11.5 & 47.5 & 26.5 & & & & \\
\hline & & & & Alberta & 11.3 & 42.1 & 19.2 \\
\hline \multirow[t]{2}{*}{ South Carolina } & 11.2 & 40.7 & 29.1 & & & & \\
\hline & & & & British Columbia & 11.2 & 40.9 & 19.8 \\
\hline California & 11.1 & 43.0 & 22.4 & & & & \\
\hline Illinois & 11.1 & 47.3 & 17.2 & & & & \\
\hline \multirow[t]{4}{*}{ Colorado } & 11.1 & 44.6 & 18.3 & & & & \\
\hline & & & & Nova Scotia & 11.1 & 41.4 & 20.5 \\
\hline & & & & Manitoba & 10.7 & 37.6 & 16.3 \\
\hline & & & & Ontario & 10.5 & 38.9 & 18.1 \\
\hline Massachusetts & 10.3 & 35.9 & 18.3 & & & & \\
\hline Missouri & 10.3 & 35.2 & 18.1 & & & & \\
\hline \multirow[t]{2}{*}{ lowa } & 10.2 & 31.8 & 8.2 & & & & \\
\hline & & & & Quebec & 10.2 & 37.7 & 19.2 \\
\hline \multirow[t]{2}{*}{ Louisiana } & 8.2 & 21.7 & 3.3 & & & & \\
\hline & & & & Prince Edward Island & 8.1 & 30.1 & 5.8 \\
\hline
\end{tabular}


medRxiv preprint doi: https://doi.org/10.1101/2021.09.15.21263635; this version posted September 20, 2021. The copyright holder for this preprint (which was not certified by peer review) is the author/funder, who has granted medRxiv a license to display the preprint in perpetuity.

It is made available under a CC-BY 4.0 International license .

\begin{tabular}{|c|c|c|}
\hline & Due to composition differences (\%) & Due to coefficient differences ${ }^{1}(\%)$ \\
\hline Total decomposition & $41.8^{\star *}$ & $58.2^{* *}$ \\
\hline \multicolumn{3}{|l|}{ Detailed } \\
\hline Age and sex & 2.5 & 8.5 \\
\hline Race and immigrant status & 8.6 & 57.1 \\
\hline Marital and parent status & -0.4 & 6.6 \\
\hline Education & -2.6 & 2.5 \\
\hline Economic factors & $33.7^{\star *}$ & -0.5 \\
\hline
\end{tabular}

${ }^{*} \mathrm{p}<.05,{ }^{* *} \mathrm{p}<.01,{ }^{* * *} \mathrm{p}<.001$

States with weighted mean pain score $\geq 15$ were designated as "hotspot" states.

The approach decomposes the difference in mean pain score in the 9 hotspot states versus all other subnational units into a part due to differences in population characteristics (composition) and due to differences in coefficients (that is, the effects of the coefficients on pain). The group "Economic factors" includes main activity, family income, and financial hardship variables. ${ }^{1}$ This part of the difference is also referred to as the unexplained part. 
medRxiv preprint doi: https://doi.org/10.1101/2021.09.15.21263635; this version posted September 20, 2021. The copyright holder for this preprint (which was not certified by peer review) is the author/funder, who has granted medRxiv a license to display the preprint in perpetuity.

It is made available under a CC-BY 4.0 International license .

Figure 1. Mean pain scores in U.S. states and Canadian provinces.

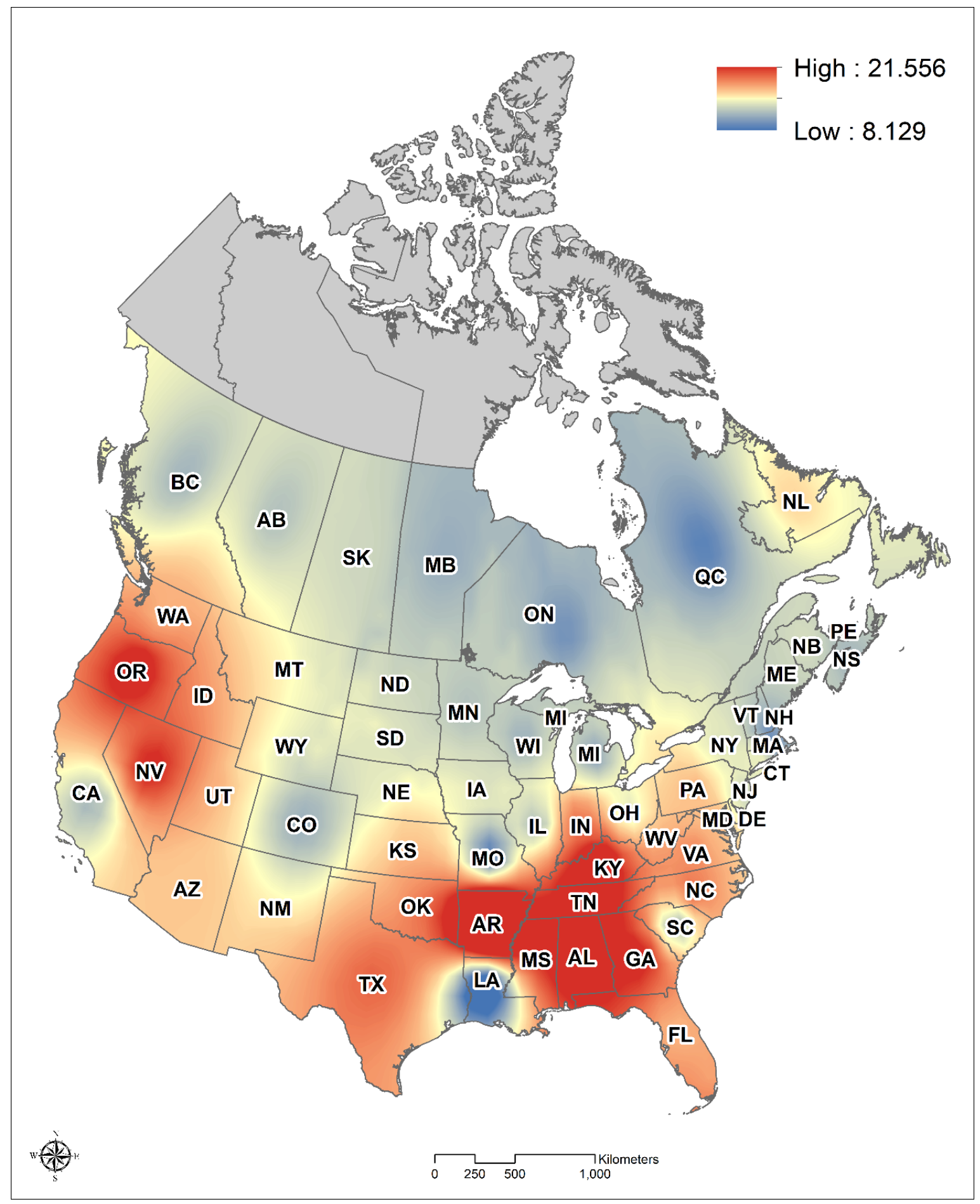

Map visualizes weighted mean pain scores in each state and province. 
medRxiv preprint doi: https://doi.org/10.1101/2021.09.15.21263635; this version posted September 20, 2021. The copyright holder for this preprint (which was not certified by peer review) is the author/funder, who has granted medRxiv a license to display the preprint in perpetuity.

It is made available under a CC-BY 4.0 International license .

\section{$\underline{\text { Supplement }}$}


medRxiv preprint doi: https://doi.org/10.1101/2021.09.15.21263635; this version posted September 20, 2021. The copyright holder for this preprint (which was not certified by peer review) is the author/funder, who has granted medRxiv a license to display the preprint in perpetuity.

It is made available under a CC-BY 4.0 International license .

\begin{tabular}{|c|c|c|c|}
\hline & U.S. & Canada & $p$-value from test of difference \\
\hline Proportion of cases in the sample & 49.9 & 50.1 & \\
\hline Age & & & $p=.214$ \\
\hline $18-24$ & 10.8 & 10.8 & \\
\hline $25-44$ & 35.3 & 32.1 & \\
\hline $45-64$ & 33.1 & 35.7 & \\
\hline $65+$ & 20.8 & 21.4 & \\
\hline Gender & & & $p<.001$ \\
\hline Men & 54.5 & 48.4 & \\
\hline Women & 44.2 & 51.4 & \\
\hline Other & 1.3 & 0.3 & \\
\hline Race/ethnicity & & & $p<.001$ \\
\hline Non-Hispanic white & 75.2 & 75.0 & \\
\hline Black & 10.0 & 2.1 & \\
\hline Hispanic & 6.1 & 1.3 & \\
\hline Asian & 4.6 & 14.3 & \\
\hline Other & 4.2 & 7.3 & \\
\hline Immigrant & 7.5 & 19.3 & $p<.001$ \\
\hline Marital status & & & $p=.044$ \\
\hline Married & 54.8 & 58.8 & \\
\hline Previously married & 13.3 & 12.7 & \\
\hline Never married & 31.9 & 28.5 & \\
\hline Has children & 53.3 & 52.2 & $p=.509$ \\
\hline Educational attainment & & & $p<.001$ \\
\hline High school or less & 22.6 & 16.1 & \\
\hline Some postsecondary education & 23.5 & 19.2 & \\
\hline AA or VTC & 10.0 & 21.0 & \\
\hline $\mathrm{BA}$ or higher & 44.0 & 43.8 & \\
\hline Main activity & & & $p<.001$ \\
\hline Employed & 54.7 & 53.8 & \\
\hline Retired & 16.7 & 23.2 & \\
\hline Unemployed & 9.2 & 5.4 & \\
\hline Disabled & 6.8 & 2.9 & \\
\hline Other & 12.6 & 14.7 & \\
\hline Family income & & & $p<.001$ \\
\hline $0-29 k$ & 33.5 & 19.4 & \\
\hline $30-59 k$ & 25.4 & 24.2 & \\
\hline $60-89 k$ & 17.1 & 22.0 & \\
\hline $90-149 k$ & 17.2 & 25.0 & \\
\hline $150 \mathrm{k}$ or more & 6.8 & 9.5 & \\
\hline Financial hardship due to COVID & & & $p<.001$ \\
\hline No & 35.7 & 42.1 & \\
\hline Slight & 40.3 & 42.1 & \\
\hline Some & 15.6 & 11.8 & \\
\hline Serious hardship & 8.4 & 4.0 & \\
\hline Pain dichotomized at $10+$ & 45.4 & 39.6 & $p<.001$ \\
\hline Pain dichotomized at $20+$ & 23.9 & 19.0 & $p<.001$ \\
\hline
\end{tabular}


medRxiv preprint doi: https://doi.org/10.1101/2021.09.15.21263635; this version posted September 20, 2021. The copyright holder for this preprint (which was not certified by peer review) is the author/funder, who has granted medRxiv a license to display the preprint in perpetuity.

It is made available under a CC-BY 4.0 International license .

\begin{tabular}{|c|c|c|c|c|c|c|c|c|c|c|}
\hline \multicolumn{11}{|c|}{ Supplemental Table S2. Negative binomial regressions of pain score on country, net of covariates. } \\
\hline & (1) & (2) & (3) & (4) & (5) & (6) & (7) & (8) & (9) & (10) \\
\hline U.S. (vs. Canada) & $1.17^{* * *}$ & $1.17^{\star \star *}$ & $1.14^{* \star *}$ & $1.13^{* *}$ & $1.11^{* *}$ & 1.07 & $1.08^{*}$ & 1.05 & $1.16^{* * *}$ & $1.08^{\star}$ \\
\hline \multicolumn{11}{|l|}{ Age $(18-24)$} \\
\hline $25-44$ & & $1.50^{\star \star \star}$ & $1.48^{* \star *}$ & $1.43^{* \star *}$ & $1.38^{* * *}$ & $1.40^{* * *}$ & $1.45^{\star \star \star}$ & $1.37^{\star * *}$ & $1.58^{\star * \star}$ & $1.43^{\star \star \star}$ \\
\hline $45-64$ & & $1.61^{* * *}$ & $1.53^{* * *}$ & $1.46^{* * *}$ & $1.30^{* * *}$ & $1.42^{\star * \star}$ & $1.48^{* * *}$ & $1.30^{* * *}$ & $1.54^{* * *}$ & $1.33^{* * *}$ \\
\hline $65+$ & & $1.48^{\star \star \star}$ & $1.38^{* * *}$ & $1.31^{* * *}$ & 1.16 & $1.23^{* *}$ & $1.45^{\star \star *}$ & 1.16 & $1.39^{* * *}$ & 1.20 \\
\hline \multicolumn{11}{|l|}{ Gender (male) } \\
\hline Female & & $1.18^{* * *}$ & $1.18^{\star * *}$ & $1.17^{* * *}$ & $1.12^{* *}$ & $1.10^{* *}$ & $1.10^{* *}$ & 1.06 & $1.12^{\star \star}$ & 1.05 \\
\hline Other & & $1.84^{* \star *}$ & $1.79^{* *}$ & $1.81^{* \star *}$ & $1.80^{* *}$ & $1.75^{\star \star \star}$ & $1.78^{\star \star \star}$ & $1.70^{\star \star}$ & $1.68^{* *}$ & $1.65^{\star *}$ \\
\hline \multicolumn{11}{|l|}{ Race (white) } \\
\hline Black & & & 0.89 & 0.88 & 0.87 & $0.80^{* *}$ & 0.90 & $0.85^{\star}$ & $0.86^{*}$ & $0.85^{\star}$ \\
\hline Hispanic & & & 0.85 & 0.86 & 0.87 & $0.80^{*}$ & 0.86 & 0.85 & 0.82 & 0.84 \\
\hline Asian & & & $0.75^{\star \star *}$ & $0.75^{\star \star *}$ & $0.78^{* * *}$ & $0.79^{* * *}$ & $0.74^{\star * *}$ & $0.80^{* * *}$ & $0.80^{* *}$ & $0.81^{* *}$ \\
\hline Other & & & 1.07 & 1.08 & 1.08 & 1.01 & 1.03 & 1.01 & 1.05 & 1.00 \\
\hline Immigrant & & & 0.90 & 0.89 & 0.92 & 0.89 & 0.90 & 0.91 & 0.94 & 0.94 \\
\hline \multicolumn{11}{|l|}{ Marital (married) } \\
\hline Previously married & & & & 1.11 & 1.06 & 0.97 & 1.11 & 0.98 & 1.09 & 0.99 \\
\hline Never married & & & & 1.03 & 1.00 & 0.92 & 0.98 & 0.92 & 0.99 & 0.92 \\
\hline Has children at home & & & & 1.08 & $1.11^{*}$ & $1.13^{\star *}$ & 1.07 & $1.12^{\star *}$ & 1.07 & $1.10^{*}$ \\
\hline \multicolumn{11}{|l|}{ Education (BA+) } \\
\hline HS or less & & & & & & & & & $1.39^{* * *}$ & $1.14^{*}$ \\
\hline Some postsecondary & & & & & & & & & $1.42^{* * *}$ & $1.20^{\star \star \star}$ \\
\hline Associate or equivalent & & & & & & & & & $1.43^{* * *}$ & $1.27^{\star * \star}$ \\
\hline \multicolumn{11}{|l|}{ Main activity (employed) } \\
\hline Retired & & & & & $1.22^{* *}$ & & & $1.25^{\star *}$ & & $1.25^{\star *}$ \\
\hline Unemployed & & & & & $1.23^{* *}$ & & & 0.97 & & 0.95 \\
\hline Disabled & & & & & $2.53^{\star * *}$ & & & $2.11^{\star \star *}$ & & $2.04^{\star \star \star}$ \\
\hline Other & & & & & 1.07 & & & 0.99 & & 0.97 \\
\hline \multicolumn{11}{|l|}{ Family income (\$0-29k) } \\
\hline$\$ 30-59 k$ & & & & & & $0.75^{\star * *}$ & & $0.87^{* *}$ & & $0.89^{*}$ \\
\hline$\$ 60-89 k$ & & & & & & $0.64^{* \star *}$ & & $0.78^{\star \star *}$ & & $0.82^{* \star *}$ \\
\hline$\$ 90-149 k$ & & & & & & $0.58^{* * *}$ & & $0.76^{* * *}$ & & $0.81^{* * *}$ \\
\hline$\$ 150 k+$ & & & & & & $0.51^{* * *}$ & & $0.68^{* * *}$ & & $0.74^{* * *}$ \\
\hline \multicolumn{11}{|l|}{ Financial hardship (no) } \\
\hline Little/slight & & & & & & & $1.36^{\star * *}$ & $1.34^{* * *}$ & & $1.35^{\star \star \star}$ \\
\hline Some & & & & & & & $1.77^{\star * *}$ & $1.62^{* \star *}$ & & $1.64^{* \star *}$ \\
\hline Serious & & & & & & & $2.43^{* * *}$ & $2.17^{\star \star *}$ & & $2.17^{\star \star \star}$ \\
\hline
\end{tabular}

${ }^{\star} \mathrm{p}<.05,{ }^{* *} \mathrm{p}<.01,{ }^{* * *} \mathrm{p}<.001$

Regression models weighted using sampling weights; IRR shown (exponentiated coefficients). Pain is a continuous variable with $0-55$ range. $\mathrm{N}=4,162$. 
medRxiv preprint doi: https://doi.org/10.1101/2021.09.15.21263635; this version posted September 20, 2021. The copyright holder for this preprint (which was not certified by peer review) is the author/funder, who has granted medRxiv a license to display the preprint in perpetuity.

It is made available under a CC-BY 4.0 International license .

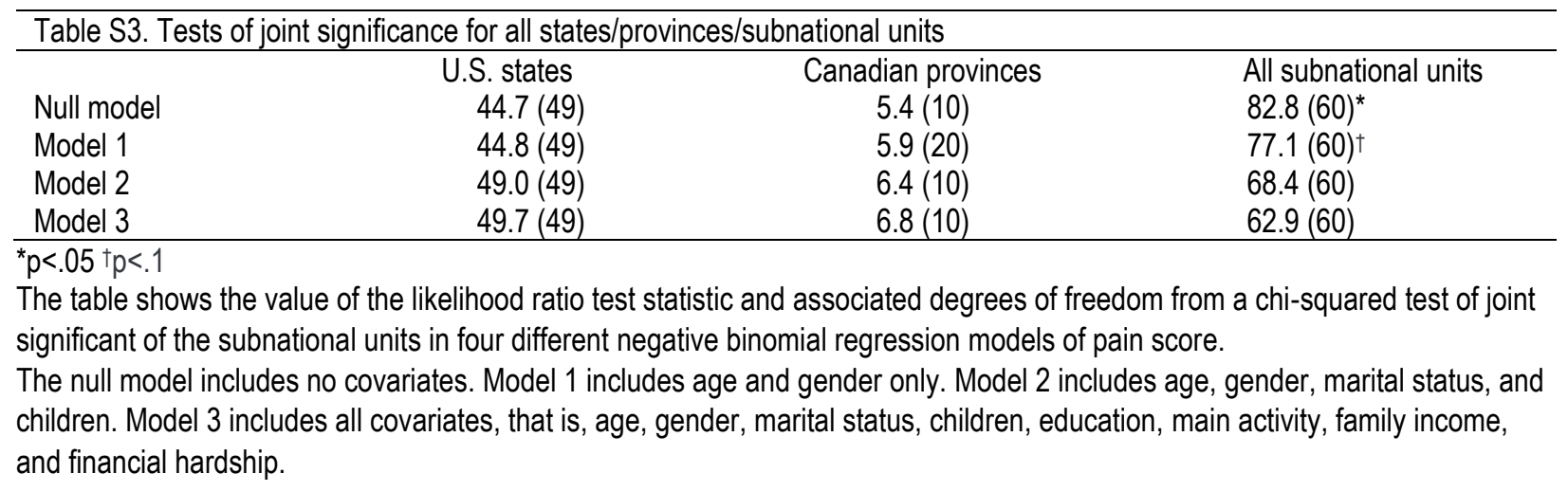


medRxiv preprint doi: https://doi.org/10.1101/2021.09.15.21263635; this version posted September 20, 2021. The copyright holder for this preprint (which was not certified by peer review) is the author/funder, who has granted medRxiv a license to display the preprint in perpetuity.

It is made available under a CC-BY 4.0 International license .

\begin{tabular}{|c|c|}
\hline \multicolumn{2}{|c|}{ Supplemental Table S4. Number of respondents in each state and province $(\mathrm{N}=4,162)$} \\
\hline Alabama & 27 \\
\hline Arizona & 48 \\
\hline Arkansas & 21 \\
\hline California & 209 \\
\hline Colorado & 25 \\
\hline Connecticut & 36 \\
\hline Delaware & 9 \\
\hline DC & 5 \\
\hline Florida & 159 \\
\hline Georgia & 53 \\
\hline Hawaii & 3 \\
\hline Idaho & 11 \\
\hline Illinois & 92 \\
\hline Indiana & 32 \\
\hline lowa & 19 \\
\hline Kansas & 16 \\
\hline Kentucky & 42 \\
\hline Louisiana & 21 \\
\hline Maine & 8 \\
\hline Maryland & 31 \\
\hline Massachusetts & 39 \\
\hline Michigan & 60 \\
\hline Minnesota & 24 \\
\hline Mississippi & 16 \\
\hline Missouri & 35 \\
\hline Montana & 9 \\
\hline Nebraska & 9 \\
\hline Nevada & 23 \\
\hline New Hampshire & 9 \\
\hline New Jersey & 52 \\
\hline New Mexico & 13 \\
\hline New York & 147 \\
\hline North Carolina & 64 \\
\hline North Dakota & 4 \\
\hline Ohio & 97 \\
\hline Oklahoma & 18 \\
\hline Oregon & 49 \\
\hline Pennsylvania & 90 \\
\hline Rhode Island & 5 \\
\hline South Carolina & 37 \\
\hline South Dakota & 4 \\
\hline Tennessee & 46 \\
\hline
\end{tabular}


medRxiv preprint doi: https://doi.org/10.1101/2021.09.15.21263635; this version posted September 20, 2021. The copyright holder for this preprint (which was not certified by peer review) is the author/funder, who has granted medRxiv a license to display the preprint in perpetuity.

It is made available under a CC-BY 4.0 International license.

\begin{tabular}{lr}
\hline Texas & 164 \\
Utah & 11 \\
Vermont & 5 \\
Virginia & 42 \\
Washington & 85 \\
West Virginia & 12 \\
Wisconsin & 39 \\
Wyoming & 2 \\
British Columbia & 287 \\
Alberta & 237 \\
Saskatchewan & 68 \\
Manitoba & 72 \\
Ontario & 761 \\
Quebec & 501 \\
New Brunswick & 45 \\
Nova Scotia & 66 \\
Prince Edward Island & 17 \\
Newfoundland and Labrador & 30 \\
Northwest Territories & 1 \\
\hline The table lists the number of respondents with valid pain information in each U.S. state and Canadian province, organized \\
alphabetically within country. Only units with 15 or more respondents are used in subnational regression analyses.
\end{tabular}


medRxiv preprint doi: https://doi.org/10.1101/2021.09.15.21263635; this version posted September 20, 2021. The copyright holder for this preprint (which was not certified by peer review) is the author/funder, who has granted medRxiv a license to display the preprint in perpetuity.

It is made available under a CC-BY 4.0 International license .

\begin{tabular}{|c|c|c|c|c|c|c|c|c|c|c|}
\hline \multicolumn{11}{|c|}{ Supplemental Table S5. Negative binomial regressions of pain score as a function of hotspot areas, net of covariates. } \\
\hline & (1) & (2) & (3) & (4) & (5) & (6) & (7) & (8) & (9) & (10) \\
\hline Hotspot states & $1.45^{\star \star *}$ & $1.42^{\star \star \star}$ & $1.41^{* * *}$ & $1.41^{* \star *}$ & $1.39^{\star * *}$ & $1.37^{* * *}$ & $1.31^{* * *}$ & $1.35^{\star * *}$ & $1.29^{\star * *}$ & $1.30^{* * *}$ \\
\hline \multicolumn{11}{|l|}{ Age $(18-24)$} \\
\hline $25-44$ & & $1.53^{\star * *}$ & $1.49^{* * *}$ & $1.44^{\star * *}$ & $1.60^{\star * *}$ & $1.38^{* * *}$ & $1.40^{* \star *}$ & $1.45^{\star \star *}$ & $1.37^{* * *}$ & $1.43^{* * *}$ \\
\hline 45-64 & & $1.60^{* \star *}$ & $1.52^{* * *}$ & $1.45^{\star * \star}$ & $1.53^{\star \star \star}$ & $1.29^{\star \star *}$ & $1.41^{* * *}$ & $1.47^{* \star *}$ & $1.29^{\star \star \star}$ & $1.32^{\star * *}$ \\
\hline $65+$ & & $1.47^{\star \star *}$ & $1.36^{\star * *}$ & $1.29^{\star \star}$ & $1.37^{\star \star *}$ & 1.16 & $1.22^{*}$ & $1.44^{\star * *}$ & 1.16 & 1.19 \\
\hline Gender (male) & & 1.00 & 1.00 & 1.00 & 1.00 & 1.00 & 1.00 & 1.00 & 1.00 & 1.00 \\
\hline Female & & $1.16^{* \star *}$ & $1.16^{\star \star \star}$ & $1.15^{\star \star \star}$ & $1.10^{*}$ & $1.11^{* *}$ & $1.09^{*}$ & $1.09^{*}$ & 1.05 & 1.04 \\
\hline Other & & $1.93^{* * *}$ & $1.85^{\star \star *}$ & $1.88^{* * *}$ & $1.76^{* *}$ & $1.85^{\star *}$ & $1.79^{\star \star *}$ & $1.82^{* * *}$ & $1.72^{\star *}$ & $1.69^{* *}$ \\
\hline \multicolumn{11}{|l|}{ Race (white) } \\
\hline Black & & & 0.91 & 0.90 & 0.88 & 0.88 & $0.80^{* *}$ & 0.90 & $0.85^{\star}$ & $0.85^{*}$ \\
\hline Hispanic & & & 0.90 & 0.90 & 0.87 & 0.91 & 0.82 & 0.88 & 0.86 & 0.86 \\
\hline Asian & & & $0.72^{\star \star \star}$ & $0.73^{\star \star \star}$ & $0.77^{\star \star \star}$ & $0.76^{\star \star \star}$ & $0.77^{\star \star \star}$ & $0.73^{\star \star \star}$ & $0.78^{\star \star \star}$ & $0.80^{\star \star \star}$ \\
\hline Other & & & 1.05 & 1.06 & 1.03 & 1.07 & 1.01 & 1.02 & 1.01 & 0.99 \\
\hline Immigrant & & & $0.88^{*}$ & $0.88^{*}$ & 0.91 & 0.91 & $0.89^{*}$ & 0.90 & 0.91 & 0.93 \\
\hline \multicolumn{11}{|l|}{ Marital (married) } \\
\hline Previously married & & & & $1.12^{*}$ & 1.10 & 1.07 & 0.97 & 1.11 & 0.98 & 0.99 \\
\hline Never married & & & & 1.03 & 1.00 & 1.00 & 0.92 & 0.98 & 0.92 & 0.92 \\
\hline Has children at home & & & & 1.09 & 1.07 & $1.12^{* *}$ & $1.14^{* *}$ & 1.07 & $1.12^{* *}$ & $1.10^{*}$ \\
\hline \multicolumn{11}{|l|}{ Education (BA+) } \\
\hline HS or less & & & & & $1.37^{\star \star \star}$ & & & & & $1.13^{*}$ \\
\hline Some postsecondary & & & & & $1.41^{* * *}$ & & & & & $1.19^{* * *}$ \\
\hline Associate or equivalent & & & & & $1.39^{\star \star \star}$ & & & & & $1.25^{\star \star \star}$ \\
\hline \multicolumn{11}{|l|}{ Main activity (employed) } \\
\hline Retired & & & & & & $1.21^{* *}$ & & & $1.25^{\star *}$ & $1.24^{* *}$ \\
\hline Unemployed & & & & & & $1.23^{\star *}$ & & & 0.97 & 0.95 \\
\hline Disabled & & & & & & $2.53^{* * *}$ & & & $2.11^{* * *}$ & $2.05^{\star * *}$ \\
\hline Other & & & & & & 1.06 & & & 0.99 & 0.97 \\
\hline \multicolumn{11}{|l|}{ Family income (\$0-29k) } \\
\hline$\$ 30-59 k$ & & & & & & & $0.75^{\star \star \star}$ & & $0.87^{* *}$ & $0.89^{*}$ \\
\hline$\$ 60-89 k$ & & & & & & & $0.64^{* * *}$ & & $0.78^{\star * *}$ & $0.81^{* * *}$ \\
\hline$\$ 90-149 k$ & & & & & & & $0.58^{* \star *}$ & & $0.77^{\star * \star}$ & $0.81^{* * *}$ \\
\hline$\$ 150 k+$ & & & & & & & $0.52^{* * *}$ & & $0.68^{* * *}$ & $0.74^{* * *}$ \\
\hline \multicolumn{11}{|l|}{ Financial hardship (no) } \\
\hline Little/slight & & & & & & & & $1.36^{\star \star \star}$ & $1.34^{\star \star \star}$ & $1.35^{\star \star *}$ \\
\hline Some & & & & & & & & $1.77^{\star \star \star}$ & $1.62^{\star \star \star}$ & $1.63^{\star * *}$ \\
\hline Serious & & & & & & & & $2.44^{\star \star \star}$ & $2.17^{\star \star \star}$ & $2.18^{\star * *}$ \\
\hline
\end{tabular}

